\title{
Prominent amyloid plaque pathology and cerebral amyloid angiopathy in APP V717I (London) carrier - phenotypic variability in autosomal dominant Alzheimer's disease
}

\author{
Grace M. Lloyd ${ }^{1,2+}$, Jorge A. Trejo-Lopez ${ }^{1,3 \dagger}$, Yuxing Xia ${ }^{1,2}$, Karen N. McFarland ${ }^{1,4,7,8}$, Sarah J. Lincoln ${ }^{5}$, \\ Nilüfer Ertekin-Taner ${ }^{5,6}$, Benoit I. Giasson ${ }^{1,2,7}$, Anthony T. Yachnis ${ }^{3}$ and Stefan Prokop ${ }^{1,3,7,8^{*}}$ (i)
}

\begin{abstract}
The discovery of mutations associated with familial forms of Alzheimer's disease (AD), has brought imperative insights into basic mechanisms of disease pathogenesis and progression and has allowed researchers to create animal models that assist in the elucidation of the molecular pathways and development of therapeutic interventions. Position 717 in the amyloid precursor protein (APP) is a hotspot for mutations associated with autosomal dominant AD (ADAD) and the valine to isoleucine amino acid substitution (V717l) at this position was among the first ADAD mutations identified, spearheading the formulation of the amyloid cascade hypothesis of AD pathogenesis. While this mutation is well described in multiple kindreds and has served as the basis for the generation of widely used animal models of disease, neuropathologic data on patients carrying this mutation are scarce. Here we present the detailed clinical and neuropathologic characterization of an APP V717I carrier, which reveals important novel insights into the phenotypic variability of ADAD cases. While age at onset, clinical presentation and widespread parenchymal beta-amyloid (Aß) deposition are in line with previous reports, our case also shows widespread and severe cerebral amyloid angiopathy (CAA). This patient also presented with TDP-43 pathology in the hippocampus and amygdala, consistent with limbic predominant age-related TDP-43 proteinopathy (LATE). The APOE $\varepsilon 2 / \varepsilon 3$ genotype may have been a major driver of the prominent vascular pathology seen in our case. These findings highlight the importance of neuropathologic examinations of genetically determined $A D$ cases and demonstrate striking phenotypic variability in ADAD cases.
\end{abstract}

Keywords: Alzheimer's disease, Amyloid precursor protein, Beta-amyloid, Cerebral amyloid angiopathy, London mutation, APOE

\section{Introduction}

Alzheimer's disease (AD) is the most common form of dementia, currently affecting more than 5 million people in the United States [6]. Neuropathological hallmarks of AD include extracellular deposits of beta-Amyloid $(A \beta)$, intracellular deposits of neurofibrillary tangles (NFT) and neuron loss [35]. The majority of cases occurs as sporadic disease (sporadic AD, $\mathrm{SAD}$ ), modified by genetic, behavioral

\footnotetext{
*Correspondence: sprokop@ufl.edu

${ }^{\dagger}$ Grace M. Lloyd and Jorge A. Trejo-Lopez contributed equally to this work. ${ }^{1}$ Center for Translational Research in Neurodegenerative Disease, University of Florida, Gainesville, FL 32610, USA

${ }^{3}$ Department of Pathology, University of Florida, Gainesville, FL 32610, USA Full list of author information is available at the end of the article
}

and environmental risk factors, while a subset of cases is caused by autosomal-dominant mutations [14, 21, 35]. These mutations in autosomal dominant forms of $\mathrm{AD}$ $(\mathrm{ADAD})$ are clustered in genes associated with the metabolism of $A \beta$-peptides, which are generated from Amyloid Precursor Protein (APP) in sequential cleavage events mediated by $\beta$ - and $\gamma$-secretase [9]. ADAD associated mutations in APP mainly cluster around these secretase cleavage sites, while codon 717 is a mutational hotspot at the $\gamma$-secretase cleavage site [27]. To date, four different pathogenic amino acid changes for APP on codon 717 have been described: Valine to Phenylalanine (V717F, Indiana [37]), Valine to Glycine (V717G [10]), Valine to Isoleucine (V717I, London $[18,63])$ and Valine to Leucine (V717L [38]). All of these 
mutations shift the ratio of $A \beta_{1-42} / A \beta_{1-40}$ towards increased production of $A \beta_{1-42}$ [27], which is more aggregation prone and can drive pathological protein accumulation. The V717I (London) mutation, was among the first mutations described to cause ADAD and this discovery has put $A \beta$ center stage in $A D$ pathogenesis. Animal models overexpressing mutant human APP are a staple of AD research [17, 24, 46, 47, 49, 52, 54] and the APP V717I mutation was used to generate some widely used models [34, 43, 54]. Despite the numerous and detailed descriptions of pathological findings in these animal models, neuropathological characterization of patients carrying the APP V717I mutation is scarce. The brain of the original case from England was reported to show $\mathrm{AD}$ neuropathological changes with mild cerebral amyloid angiopathy (CAA) as well as Lewy body (LB) pathology in cortical and brainstem regions, while findings from an American family with this mutation showed AD pathology but no CAA or LB $[8,22,36]$.

\section{Case presentation}

The patient was a sixty-six (66) year-old right-handed Caucasian female with a past medical history of thyroid disease. Her family history was notable for extensive AD, involving her mother (deceased from disease at age 62), two aunts (deceased from disease at ages 66 and 68), and a grandfather (also deceased from disease). Additionally, she had a brother diagnosed with AD, still living in a nursing facility.

She was first noted to develop neurologic symptoms in her mid-fifties, manifesting primarily as progressive memory loss. She presented for formal neurologic evaluation at age 60 , at which time her husband described significant memory difficulty, confusion, and occasional difficulty in finishing sentences. While she had discontinued working five years prior to evaluation due to difficulty with completing occupational tasks, she maintained her ability to finish routine housework. On initial evaluation, she was oriented to person, place, and time but not year, with a Mini Mental Status Exam (MMSE) score of 17. Physical exam findings included the presence of a tremor of her head and bilateral hands, with a negative Romberg's test. These findings were assessed to be consistent with AD of moderate intensity, and she was started on donepezil and memantine therapy. Concurrent computed tomography (CT) imaging of her brain demonstrated subtle areas of low-attenuation in the periventricular white matter of the parietal lobe, suggestive of microvascular ischemic change.

Two years after initial diagnosis, she was noted to demonstrate significant clinical deterioration during a followup clinical visit. Her husband described a loss of her ability to maintain independent activities of daily living, becoming dependent on him for bathing and dressing on a daily basis, and that she had additionally developed urinary incontinence. Her recent medical history was notable for a hospital admission due to dehydration and severe hypothyroidism secondary to thyroid medication noncompliance. On evaluation, she exhibited depression, anxiety, confusion, and an MMSE score of 8 . These findings were assessed to be consistent with a progression to severe AD. CT imaging at this time revealed mild global brain parenchymal loss, with no evidence of focal lesions or asymmetric atrophy.

Her symptoms continued to progress, whereupon at a follow-up visit four years after initial diagnosis, her husband described the development of intermittent jerking movements by the patient, occurring a few times per week and lasting approximately $15 \mathrm{~min}$ in duration. At this visit, she was oriented only to person, and her MMSE score was 0 , because she was unable to follow commands. A subsequent electroencephalogram revealed no focal abnormalities or epileptiform activity, noting only the presence of diffuse slowing activity, consistent with moderate encephalopathy.

By the time of her final follow-up visit approximately, six years after initial diagnosis, she had developed a wide-based gait with frequent falls, aphasia, personality changes, poor insight, and complete lack of orientation to time, place, and person. She ultimately passed away within six months of her last visit, at age 66 . Her family consented to neuropathologic evaluation of her brain by the Center for Translational Research in Neurodegenerative Disease (CTRND) at the University of Florida.

\section{Molecular studies}

A directed Sanger Sequencing screening panel for autosomal dominant mutations of APP, PSEN1, and PSEN2 identified a guanine-to-adenine single nucleotide substitution at codon 717, resulting in a Valine to Isoleucine amino acid change (APP NM_000484.3 c2149G > A pVa1717Ile, Fig. 1a). A PCR-based molecular assay for the $A P O E$ gene revealed the patient's genotype to be $\varepsilon 2 /$ $\varepsilon 3$ (for details see Additional file 1).

\section{Neuropathological evaluation}

The post-mortem interval prior to brain procurement was eight hours, with a fresh brain weight of $1080 \mathrm{~g}$ (for details see Additional file 1). Diffuse cerebral atrophy, with relative preservation of the cerebellum (Fig. 1b, c) was noted. Minimal to no atherosclerotic changes associated with the basal vasculature were identified. Serial coronal sections of cerebral hemispheres confirmed a mild to moderate degree of atrophy, with blunting of the lateral angles of the ventricles and sulcal widening most appreciable along the Sylvian fissure. No focal lesions were otherwise observed in the remainder of the cerebrum, brain stem, or cerebellum.

Microscopic examination demonstrated extensive neuronal loss and associated gliosis in the hippocampus and 


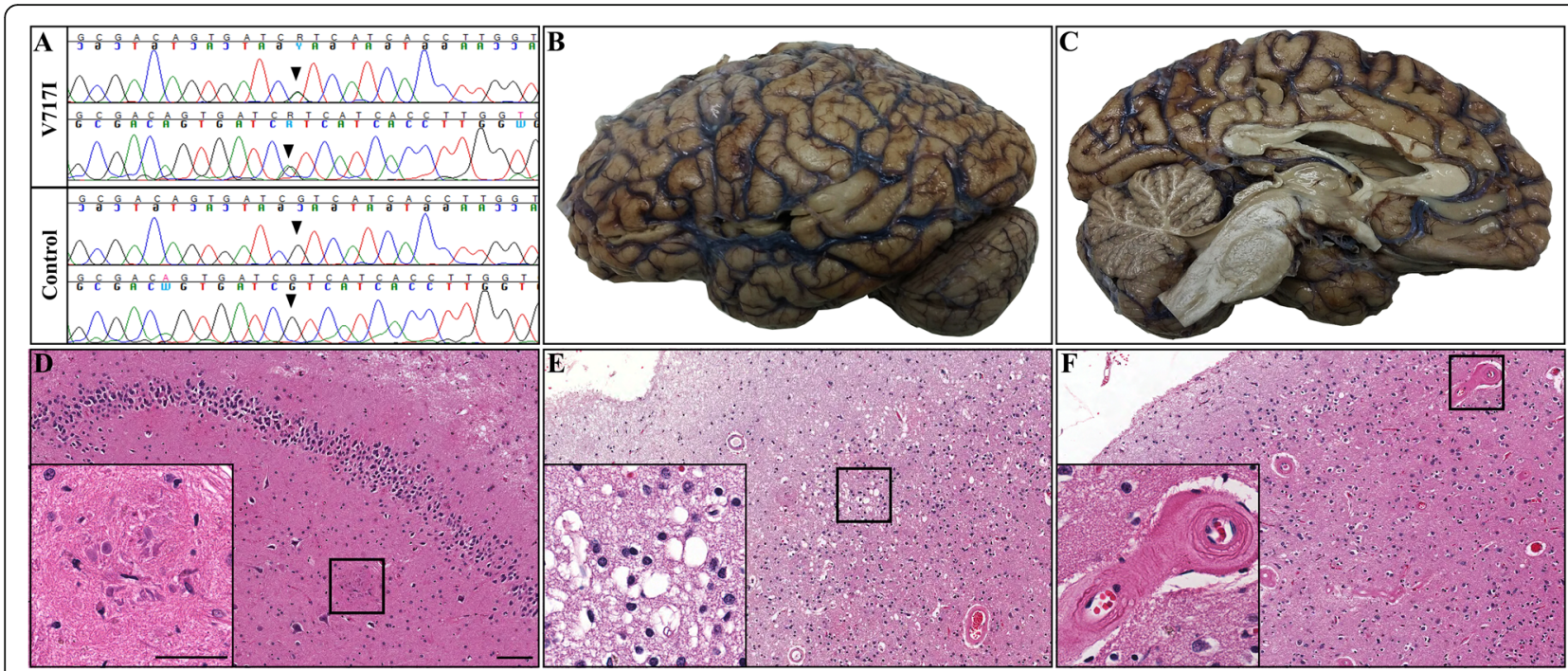

Fig. 1 (a) Representative chromatogram of Sanger-sequencing revealed a guanine-to-adenine single nucleotide substitution at codon 717 of APP, resulting in a Valine to Isoleucine amino acid change in the ADAD patient (APP NM_000484.3 c2149G > A pVal717lle). (b, c) Representative gross images of formalin-fixed left hemibrain. ( $\mathbf{d}$ - $\mathbf{f}$ ) Representative overview (scale bar $=2000 \mu \mathrm{m}$ ) and high magnification (insert, scale bar $=50 \mu \mathrm{m}$ ) images of H\&E stained sections reveal neuron loss, astrogliosis and numerous neuritic plaques (d), superficial spongiosis (e), as well as substantial amyloid angiopathy of superficial cortical and leptomeningeal vessels (f)

neocortical areas, with numerous pyramidal neurons notable for flame-shaped neurofibrillary tangles. Multiple areas demonstrated prominent neuritic plaques (Fig. 1d, insert) with associated areas of neuronal loss, gliosis, and variable vacuolization and spongiosis of superficial cortical layers (Fig. 1e). In addition, extensive cerebral amyloid angiopathy (CAA) was apparent throughout parts of cerebrum and cerebellum, concentrating on superficial cortical and leptomeningeal blood vessels (Fig. 1f). In contrast, only mild small vessel hyalinization of the basal ganglia and white matter were identified, with focal calcification of globus pallidus blood vessels. A remote microhemorrhage was identified in the primary sensory cortex. The brainstem and cerebellum demonstrated no major neuropathologic changes, with no significant neuronal loss, gliosis, or Lewy bodies identified in the substantia nigra or locus coeruleus.

Immunohistochemistry (for details see Additional files 1 and 2) with a pan-A $\beta$ antibody (4G8) demonstrated a

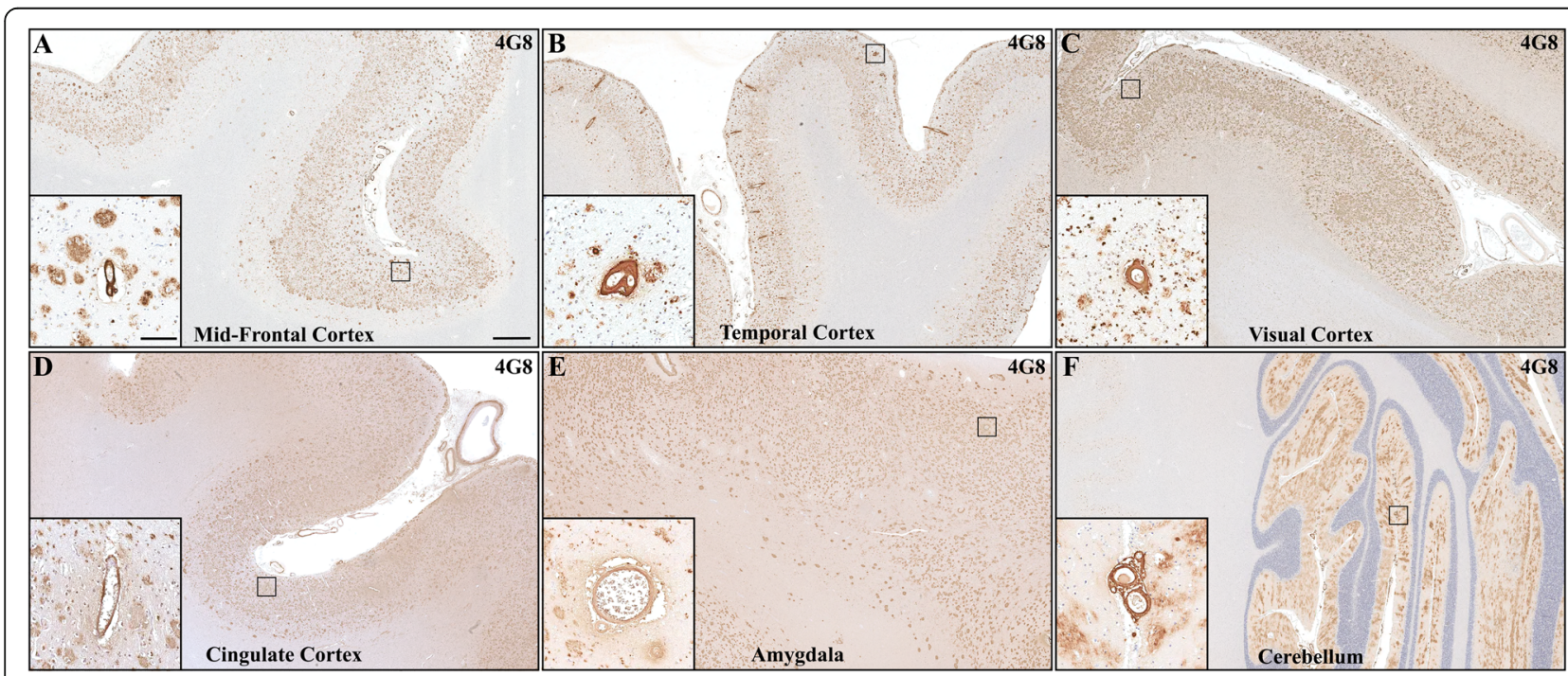

Fig. 2 Representative images of 4G8-stained sections of mid-frontal cortex (a), superior temporal gyrus (b), visual cortex (c), cingulate gyrus (d), amygdala (e) and cerebellum (f) reveal widespread parenchymal and vascular (inserts) Aß-pathology throughout the neuroaxis. Cerebral amyloid angiopathy was more prominent in cortical and leptomeningeal vasculature with no substantial involvement of cortical capillaries. Overview images (scale bar $=1000 \mu \mathrm{m})$ and high magnification insert (scale bar $=50 \mu \mathrm{m})$ 
very high $A \beta$ plaque burden throughout the cerebral neocortex (Fig. 2a-d), the amygdala (Fig. 2e), basal ganglia, and tegmentum of the midbrain and pontine brainstem. $A \beta$ deposition was also identified in the cerebellum, presenting as scattered fleecy diffuse plaques and neuritic plaques in the molecular layer of the cerebellar cortex (Fig. 2f). These findings translated to Thal phase 5 of $\mathrm{A} \beta$ deposition, corresponding to an "A3" plaque score according to the 2012 NIA-AA criteria [35]. The majority of $A \beta$ plaques were surrounded by dystrophic neurites (Fig. 3d), with the frequency of neuritic plaques throughout the neuroaxis corresponding to a CERAD semiquantitative score of "frequent" (C3) [35].

Immunostaining for tau demonstrated a concordant pattern of severe, widespread inclusion pathology, manifesting as a heavy burden of intraneuronal neurofibrillary tangles (NFT) and dystrophic neurites associated with amyloid plaques (Fig. 3a-d). Disease topography extended from the entorhinal cortex and adjacent mesial temporal lobe cortex, deep cerebral gray matter structures, to several areas of neocortex including primary visual cortex (Fig. 3a-c). These findings correspond to an advanced Braak stage (VI), translating to a "B3" NFT score [35].

In addition, intracytoplasmic neuronal inclusions were highlighted in the hippocampal subiculum and amygdala by immunohistochemistry for TDP-43 (Fig. 3e-f), while neocortical areas were devoid of TDP-43 pathology, corresponding to stage 2 of the recently defined limbicpredominant age-related TDP-43 encephalopathy neuropathologic change (LATE-NC [41]). No $\alpha$-synuclein immunoreactive pathology was identified in the examined sections of cerebrum, brainstem, or cerebellum (data not shown).

$\mathrm{A} \beta$ pathology was additionally noted to manifest as severe, widespread cerebral amyloid angiopathy (CAA), with a predilection for the superficial cortical and leptomeningeal vasculature and relative sparing of cortical capillaries (CAA type 2, [58]). Prominent vascular A $\beta$ deposits were detected in multiple neocortical areas (Fig. 2a-c), limbic areas (Fig. 2d-e) and the cerebellum (Fig. 2f), while sections from thalamus, basal ganglia, pons and medulla did not show vascular $A \beta$-deposits. This corresponds to CAA stage 2 according to Thal et al. [57]. Focal double barreling (Fig. 2b) and disruption of vessel wall integrity was noted, corresponding to severe CAA [61] or grade 4 CAA [44]. Vascular A $\beta$ deposits showed strong immunoreactivity with pan- $A \beta$ antibodies (4G8, Fig. 4a), and were labelled with $A \beta_{1-42}$ specific antibodies (12F4, Fig. 4b), as well as $A \beta_{1-40}$ specific antibodies (13.1.1 [31], Fig. 4c). In contrast, parenchymal $A \beta$ plaques were labelled strongly with pan- $A \beta$ (Fig. 4a) and $\mathrm{A} \beta_{1-42}$ specific (Fig. $4 \mathrm{~b}$ ) antibodies, while $A \beta_{1-40}$ specific antibodies only stained a minority of $A \beta$-plaques (Fig. 4c). We contrasted these results with staining in two cases of SAD with different APOE genotype (APOE $\varepsilon 3 / \varepsilon 3$ and APOE $\varepsilon 4 / \varepsilon 4$, for details see Additional file 3: Table S2). While CAA in both SAD cases showed a similar pattern of immunoreactivity with pan- $\mathrm{A} \beta$ antibodies (Fig. $4 \mathrm{~d}, \mathrm{~g}$ ), as well as $A \beta_{1-42}$ (Fig. 4e, h) and $A \beta_{1-40}$ specific antibodies (Fig. 4f, i) compared to our ADAD case (Fig. 4 A-C),

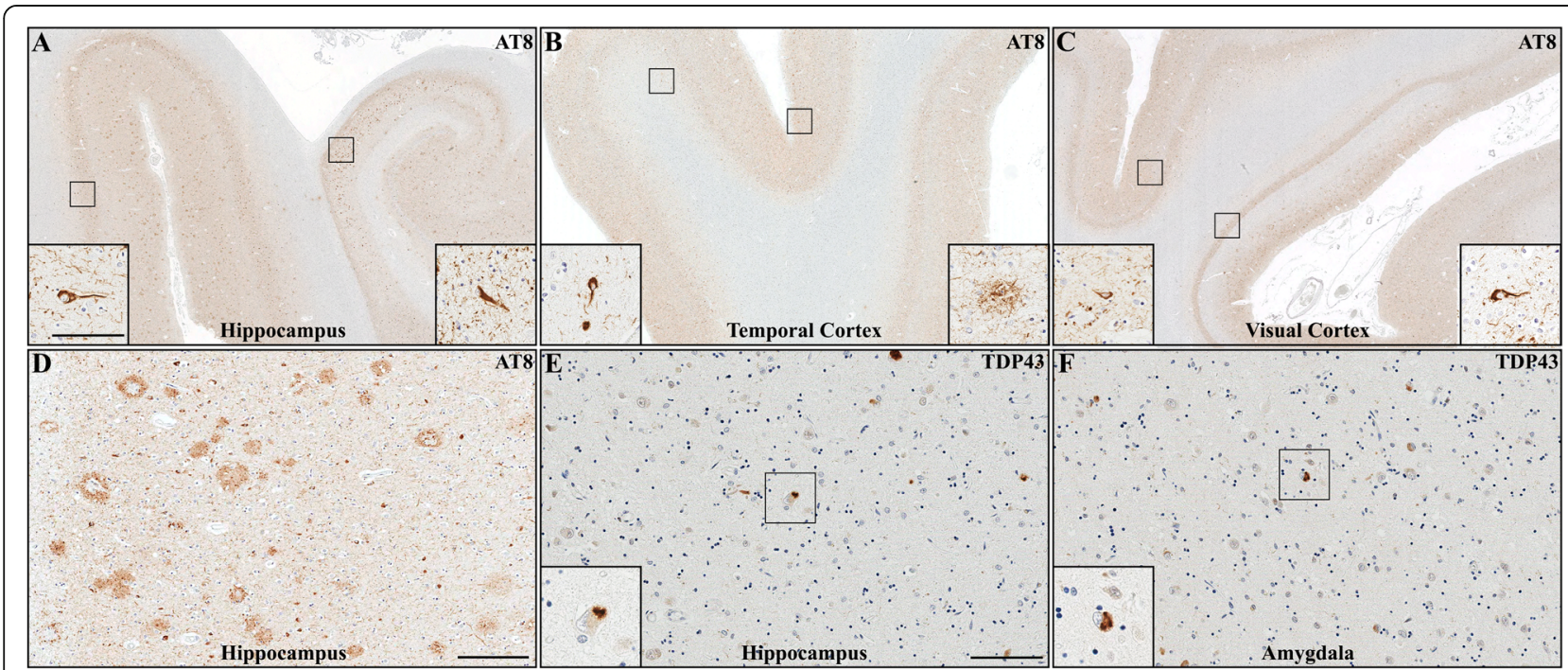

Fig. 3 Representative overview (scale bar $=2000 \mu \mathrm{m}$ ) and high magnification (insert, scale bar $=50 \mu \mathrm{m}$ ) images of AT8 staining in APP V717l mutation carrier for the hippocampus (a), superior temporal gyrus (b) and visual cortex (c) reveal substantial NFT pathology in all regions examined. (d) AT8 staining also reveals "frequent" neuritic plaques in the inferior temporal cortex (scale bar $=1000 \mu \mathrm{m}$, insert scale bar $=50 \mu \mathrm{m}$ ). Representative overview (scale bar $=2000 \mu \mathrm{m}$ ) and high magnification (insert, scale bar $=50 \mu \mathrm{m}$ ) images of TDP-43 staining demonstrate TDP-43 positive inclusions in hippocampus (e) and amygdala (f) 


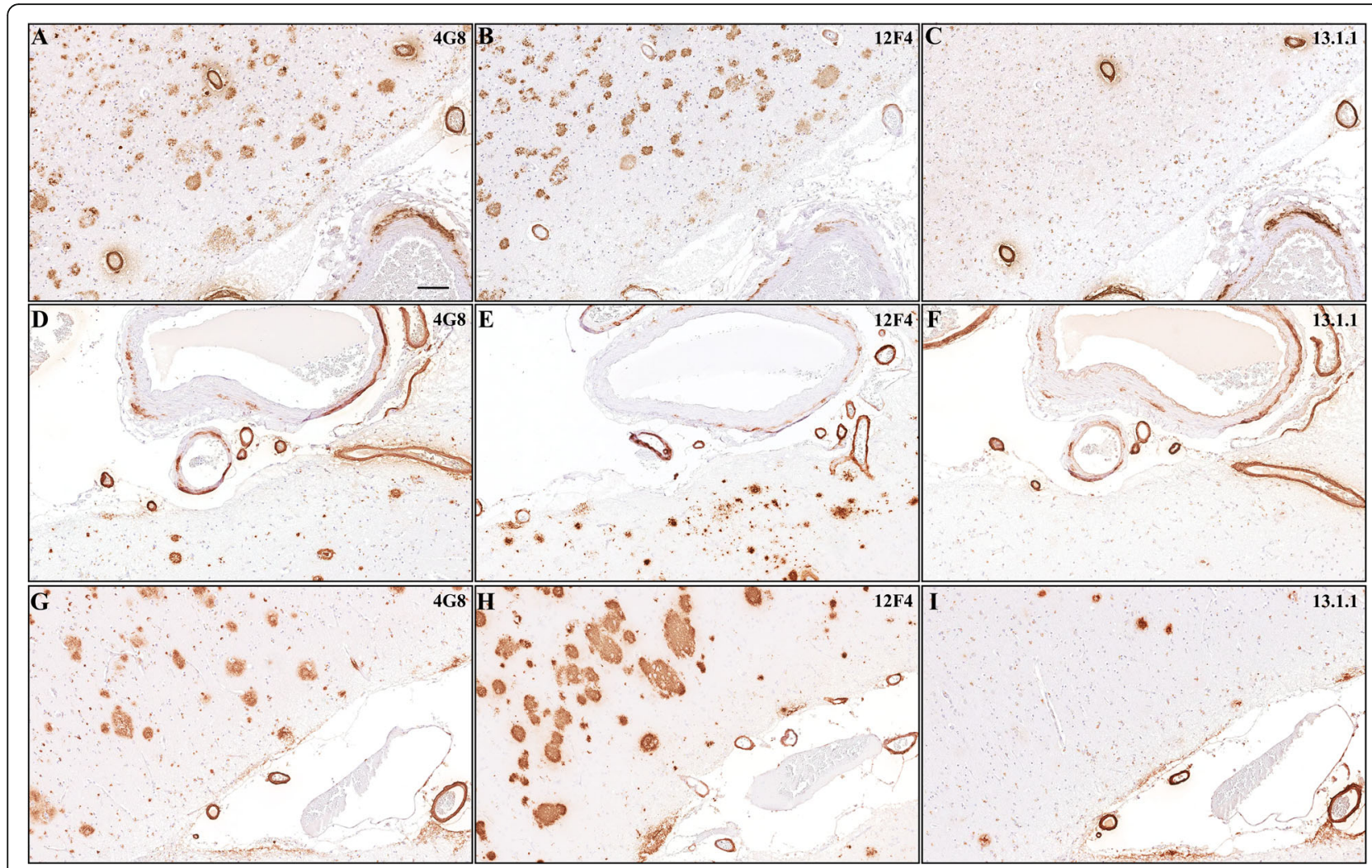

Fig. 4 (a - c) Representative images of superior temporal cortex sections of APP V717l mutation carrier labelled with pan-A (4G8, a) antibodies, demonstrate strong labeling of parenchymal and vascular amyloid deposits. Vascular deposits also showed strong staining with $A \beta_{1-42} s p e c i f i c$ antibodies $(12 \mathrm{~F} 4, \mathbf{b})$ and $A \beta_{1-40}$ specific antibodies (13.1.1, c). Parenchymal amyloid deposits demonstrated strong $A \beta_{1-42}$ positivity $(12 F 4$, b), while being scarcely labelled with $A \beta_{1-40}$ specific antibodies $(13.1 .1, \mathbf{c})$. Vascular amyloid in two SAD cases with different APOE genotype $(\varepsilon 3 / \varepsilon 3$ $(\mathbf{d}-\mathbf{f})$ and $\varepsilon 4 / \varepsilon 4(\mathbf{g}-\mathbf{i}))$, showed a similar staining pattern with strong positivity for pan-A $\beta$ antibodies $(4 G 8, \mathbf{d}, \mathbf{g})$, as well as $A \beta_{1-42}(\mathbf{e}, \mathbf{h})$ and $A \beta_{1-}$ 40 specific antibodies $(\mathbf{f}, \mathbf{i})$. Parenchymal amyloid in SAD cases were highlighted with pan-A $\beta(\mathbf{d}, \mathbf{g})$ and $A \beta_{1-42}$ specific antibodies $(\mathbf{e}, \mathbf{h})$, and showed some reactivity with $A \beta_{1-40}$ specific antibodies (f, i). Overview images (scale bar $=100 \mu \mathrm{m}$ )

parenchymal deposits were highlighted to a much greater extent with $\mathrm{A} \beta_{1-40}$ antibodies (Fig. 4F, I) than in our ADAD case (Fig. 4c).

\section{Discussion and conclusions}

The identification of missense mutations in APP underlying familial forms of $\mathrm{AD}$ has paved the way for the formulation of the "amyloid cascade hypothesis" $[16,22]$ by placing the generation of $A \beta$ peptides as central to disease pathophysiology. To date, more than 50 mutations in APP associated with early onset $\mathrm{AD}$ have been described $[9,16,29,50,55]$; rare APP variants associated with protective properties have also been reported [28]. Several different substitutions of the intramembranous Valine residue at position 717 of APP have been described to be associated with familial forms of $\mathrm{AD}$ $[10,18,37,38]$. This position is near the $\gamma$-secretase cleavage site of APP, such that amino acid substitutions at this functional locus lead to an increased ratio of $A \beta_{1-42} / A \beta_{1-40}$ with a trend towards increased production of $A \beta_{1-42}[15,27,49]$.

The patient described here carrying the APP V717I mutation presented with extensive $\mathrm{AD}$ neuropathological changes, including abundant and widespread $A \beta$-pathology in cerebrum, subcortical nuclei, and cerebellum. Multiple different types of plaques were noted, including coreplaques, diffuse plaques and subpial band-like $\mathrm{A} \beta$ deposits. All of the deposits showed a uniformly strong staining pattern with $A \beta_{1-42}$ specific antibodies and relative scarcity of $A \beta_{1-40}$ positivity compared to SAD cases, in line with the reported increase in $A \beta_{1-42}$ with this mutation in cell culture studies [27]. The majority of $A \beta$-deposits were associated with dystrophic neurites containing phosphorylated tau species. In addition, widespread neuronal tau pathology in the form of NFT, as well as neuropil thread pathology were noted. While no concomitant $\alpha$-synuclein pathology was detected, TDP-43 positive inclusions were observed in the amygdala and hippocampus. Co-occurring TDP-43 pathology in carriers of APP mutations is not as common as in sporadic (late-onset) AD but has been reported [11]. This is in line with a contribution of age to the preponderance of TDP-43 positive pathology and ties in with the recently proposed entity of limbic-predominant TDP-43 neuropathological changes (LATE-NC) [41]. In addition, 
severe and widespread CAA was noted, affecting leptomeningeal and cortical blood vessels, but sparing fine capillaries. Systematic studies on CAA in ADAD cases are scarce, but a recent report from the National Alzheimer Coordinating Center (NACC) showed an increased CAA score in ADAD compared to SAD [48]. The number of APP mutation carriers in this study were limited, but phenotypic variability with respect to CAA severity was observed. Vascular amyloid in our ADAD case was strongly labelled with pan- $A \beta$, as well as $A \beta_{1-42}$ and $A \beta_{1-40}$ specific antibodies in a similar pattern as observed in two SAD cases with different APOE genotype. The relative abundance of $A \beta$ species in parenchymal and vascular deposits has been a matter of intense debate. Initial reports suggested that the majority of vascular $A \beta$ is $A \beta_{1-40}[1,19,25,26,45]$, but subsequently a substantial contribution of $A \beta_{1-42}$ to vascular $A \beta$-deposition was acknowledged $[1,19,40,51,60]$, with some reports suggesting $A \beta_{1-42}$ deposition driving more severe CAA [4, 20]. Mechanistic studies in murine models indicate that initial deposition of $A \beta_{1-42}$ may be necessary to drive subsequent $A \beta_{1-40}$ deposition in blood vessels [33, 42], but the impact of different APOE genotypes has not been analyzed systematically in this context. The relative sparing of capillary vessels by pathologic $A \beta$ deposits, referred to as type 2 CAA [58] was previously reported to be associated with the presence of at least one $A P O E \varepsilon 2$ allele [2, 32, 59]. $A P O E$ is currently the strongest known genetic risk factor of $\mathrm{AD}$, with the $\varepsilon 4$ isoform correlating to an increased incidence of AD in people of European descent [56]. The $\varepsilon 3$ allele is associated with preservation of synaptic integrity in old human APP (hAPP) mice [7], and mediation of amyloid clearance in comparison to $\varepsilon 4$ [5], but it was also correlated to an earlier age of onset than $\varepsilon 4$ in this model $[7,30]$. The $\varepsilon 2$ genotype was studied in several Italian families with the APP V717I mutation. It was discovered that this allele was associated with a delayed age of onset compared to individuals with the same $A P P$ mutation but $A P O E$ \&3 homozygotes or $\varepsilon 4$ carriers $[23,39,53]$. Furthermore, a recent report demonstrated protective effects of the Christchurch $A P O E$ variant in a carrier of the Presenilin (PSEN) E280A mutation [3]. These diseasemodifying effects of the $A P O E$ genotype may provide one possible explanation for the divergent phenotypes seen in the clinical and neuropathological presentation of ADAD.

The case presented herein underscores the importance of neuropathological characterization of genetically determined cases of AD. Such examinations serve to identify phenotypic diversity within the disease, clarify potential modifiers of disease progression (such as, but no limited to, APOE genotype), explore the complex interrelations between disease mechanisms, and ultimately aid in elucidating potential therapeutic targets.

\section{Supplementary information}

Supplementary information accompanies this paper at https://doi.org/10. 1186/s40478-020-0891-3.

Additional file 1. Materials and Methods [12, 13, 31, 35, 62]

Additional file 2: Table S1. List of Antibodies used for this study

Additional file 3: Table S2. Summary of patient samples used in this study $[35,41,61]$

\begin{abstract}
Abbreviations
ABC: Avidin-biotin complex; AD: Alzheimer's disease; ADAD: Autosomal dominant AD; APOE: Apolipoproteins-E; APP: Amyloid precursor protein; Aß: Beta-Amyloid; CAA: Cerebral amyloid angiopathy; CT: Computed tomography; CTRND: Center for Translational Research in Neurodegenerative Disease; DAB: 3,3'-diaminobenzidine; FAD: Familial Alzheimer's disease; FBS: Fetal bovine serum; hAPP: Human amyloid precursor protein; HIER: Heat-induced epitope retrieval; LATE-NC: Limbic-predominant TDP-43 neuropathological changes; MMSE: Mini Mental Status Exam; NFT: Neurofibrillary tangles; PBS: Phosphate buffered saline; PS1: Presenilin 1; PS2: Presenilin 2; RT: Room temperature; SAD: Sporadic Alzheimer's disease; UF HBTB: University of Florida Neuromedicine Human Brain Tissue Bank
\end{abstract}

\section{Acknowledgements}

Antibodies AB5 and 13.1.1 were a generous gift from the lab of Dr. Todd Golde [31].

\section{Authors' contributions}

JTL, SP and ATY confirmed neuropathologic diagnosis. SP, ATY, GML, JTL and BG co-wrote the manuscript. JTL, GML and YX performed immunohistochemical stains, optimized protocols and prepared figures. NET, KNM and SJL performed molecular/genetic analysis. All authors read and approved the manuscript.

\section{Funding}

This study was supported by the 1Florida ADRC, funded by NIH/NIA grant P50 AG047266. NET is funded by RF1 AG051504, R01 AG061796 and U01 AG046139 which supported part of this study.

\section{Availability of data and materials}

All data generated or analyzed during this study are included in this published article.

\section{Ethics approval and consent to participate}

Staining of human tissue samples was performed with approval of the University of Florida institutional review board.

\section{Consent for publication}

Informed consent was obtained according to guidelines of the University of Florida institutional review board.

\section{Competing interests}

The authors declare that they have no competing interests.

\section{Author details}

${ }^{1}$ Center for Translational Research in Neurodegenerative Disease, University of Florida, Gainesville, FL 32610, USA. ${ }^{2}$ Department of Neuroscience, University of Florida, Gainesville, FL 32610, USA. ${ }^{3}$ Department of Pathology, University of Florida, Gainesville, FL 32610, USA. ${ }^{4}$ Department of Neurology, University of Florida, Gainesville, FL 32610, USA. ${ }^{5}$ Department of Neuroscience, Mayo Clinic, Jacksonville, FL 32224, USA. ${ }^{6}$ Department of Neurology, Mayo Clinic, Jacksonville, FL 32224, USA. ${ }^{7}$ McKnight Brain Institute, University of Florida, Gainesville, FL 32610, USA. ${ }^{8}$ Fixel Institute for Neurological Diseases, University of Florida, Gainesville, FL 32610, USA. 
Received: 24 January 2020 Accepted: 30 January 2020

\section{10.0}

\section{References}

1. Akiyama H, Mori H, Sahara N, Kondo H, Ikeda K, Nishimura T, Oda T, McGeer PL (1997) Variable deposition of amyloid $\beta$-protein (AB) with the carboxyterminus that ends at residue valine $40(A B 40)$ in the cerebral cortex of patients with Alzheimer's disease: a double-labeling immunohistochemical study with antibodies. Neurochem Res 22:1499-1505. https://doi.org/10. 1023/A:1021910729963

2. Allen N, Robinson AC, Snowden J, Davidson YS, Mann DMA (2014) Patterns of cerebral amyloid angiopathy define histopathological phenotypes in Alzheimer's disease. Neuropathol Appl Neurobiol 40:136-148. https://doi. org/10.1111/nan. 12070

3. Arboleda-Velasquez JF, Lopera F, O'Hare M, Delgado-Tirado S, Marino C, Chmielewska N, Saez-Torres KL, Amarnani D, Schultz AP, Sperling RA, Leyton-Cifuentes D, Chen K, Baena A, Aguillon D, Rios-Romenets S, Giraldo M, Guzmán-Vélez E, Norton DJ, Pardilla-Delgado E, Artola A, Sanchez JS, Acosta-Uribe J, Lalli M, Kosik KS, Huentelman MJ, Zetterberg H, Blennow K, Reiman RA, Luo J, Chen Y, Thiyyagura P, Su Y, Jun GR, Naymik M, Gai X, Bootwalla M, Ji J, Shen L, Miller JB, Kim LA, Tariot PN, Johnson KA, Reiman EM, Quiroz YT (2019) Resistance to autosomal dominant Alzheimer's disease in an APOE3 Christchurch homozygote: a case report. Nat Med 25. https:// doi.org/10.1038/s41591-019-0611-3

4. Attems J, Lintner F, Jellinger KA (2004) Amyloid $\beta$ peptide 1-42 highly correlates with capillary cerebral amyloid angiopathy and Alzheimer disease pathology. Acta Neuropathol 107:283-291. https://doi.org/10.1007/s00401-004-0822-6

5. Beffert U, Aumont N, Dea D, Lussier-Cacan S, Davignon J, Poirier J (1999) Apolipoprotein E isoform-specific reduction of extracellular amyloid in neuronal cultures. Brain Res Mol Brain Res 68:181-185. https://doi.org/10. 1016/s0169-328x(99)00073-x

6. Brookmeyer R, Abdalla N, Kawas CH, Corrada MM (2018) Forecasting the prevalence of preclinical and clinical Alzheimer's disease in the United States. Alzheimers Dement 14:121-129. https://doi.org/10.1016/j.jalz.2017.10.009

7. Buttini M, Yu GQ, Shockley K, Huang Y, Jones B, Masliah E, Mallory M, Yeo T, Longo FM, Mucke L (2002) Modulation of Alzheimer-like synaptic and cholinergic deficits in transgenic mice by human apolipoprotein $\mathrm{E}$ depends on isoform, aging, and overexpression of amyloid $\beta$ peptides but not on plaque formation. J Neurosci 22:10539-10548. https://doi.org/10.1523/ jneurosci.22-24-10539.2002

8. Cairns NJ, Chadwick A, Lantos PL, Levy R, Rossor MN (1993) Beta A4 protein deposition in familial Alzheimer's disease with the mutation in codon 717 of the beta A4 amyloid precursor protein gene and sporadic Alzheimer's disease. Neurosci Lett 149:137-140. https://doi.org/10.1016/03043940(93)90755-a

9. Carmona S, Hardy J, Guerreiro R (2018) The genetic landscape of Alzheimer disease. Handb Clin Neurol 148:395-408. https://doi.org/10.1016/B978-0444-64076-5.00026-0

10. Chartier-Harlin MC, Crawford F, Houlden H, Warren A, Hughes D, Fidani L, Goate A, Rossor M, Roques P, Hardy J (1991) Early-onset Alzheimer's disease caused by mutations at codon 717 of the beta-amyloid precursor protein gene. Nature 353:844-846. https://doi.org/10.1038/353844a0

11. Davidson YS, Raby S, Foulds PG, Robinson A, Thompson JC, Sikkink S, Yusuf I, Amin H, DuPlessis D, Troakes C, Al-Sarraj S, Sloan C, Esiri MM, Prasher VP, Allsop D, Neary D, Pickering-Brown SM, Snowden JS, Mann DM (2011) TDP43 pathological changes in early onset familial and sporadic Alzheimer's disease, late onset Alzheimer's disease and Down's syndrome: association with age, hippocampal sclerosis and clinical phenotype. Acta Neuropathol 122:703-713. https://doi.org/10.1007/s00401-011-0879-y

12. Dhillon J-KS, Riffe C, Moore BD, Ran Y, Chakrabarty P, Golde TE, Giasson BI (2017) A novel panel of a-synuclein antibodies reveal distinctive staining profiles in synucleinopathies. PLoS One 12:e0184731. https://doi.org/10. 1371/journal.pone.0184731

13. Duda JE, Giasson Bl, Gur TL, Montine TJ, Robertson D, Biaggioni I, Hurtig HI, Stern MB, Gollomp SM, Grossman M, Lee VM, Trojanowski JQ (2000) Immunohistochemical and biochemical studies demonstrate a distinct profile of alpha-synuclein permutations in multiple system atrophy. J Neuropathol Exp Neurol 59:830-841. https://doi.org/10.1093/jnen/59.9.830

14. Duyckaerts C, Potier MC, Delatour B (2008) Alzheimer disease models and human neuropathology: similarities and differences. Acta Neuropathol 115: 5-38. https://doi.org/10.1007/s00401-007-0312-8
15. Fagan AM, Watson M, Parsadanian M, Bales KR, Paul SM, Holtzman DM (2002) Human and murine ApoE markedly alters A beta metabolism before and after plaque formation in a mouse model of Alzheimer's disease. Neurobiol Dis 9:305-318. https://doi.org/10.1006/nbdi.2002.0483

16. Finckh U, Kuschel C, Anagnostouli M, Patsouris E, Pantes GV, Gatzonis S, Kapaki E, Davaki P, Lamszus K, Stavrou D, Gal A (2005) Novel mutations and repeated findings of mutations in familial Alzheimer disease. Neurogenetics 6:85-89. https://doi.org/10.1007/s10048-005-0211-x

17. Games D, Adams D, Alessandrini R, Barbour R, Borthelette P, Blackwell C, Carr T, Clemens J, Donaldson T, Gillespie F, Guido T, Hagopian S, JohnsonWood K, Khan K, Lee M, Leibowitz P, Lieberburg I, Little S, Masliah E, Mc Conlogue L, Montoya-Zavala M, Mucke L, Paganini L, Penniman E, Power M, Schenk D, Seubert P, Snyder B, Soriano F, Tan H, Vitale J, Wadsworth S, Wolozin B, Zhao J (1995) Alzheimer-type neuropathology in transgenic mice overexpressing V717F $\beta$-amyloid precursor protein. Nature 373:523-527. https://doi.org/10.1038/373523a0

18. Goate A, Chartier-Harlin MC, Mullan M, Brown J, Crawford F, Fidani L, Giuffra L, Haynes A, Irving N, James L (1991) Segregation of a missense mutation in the amyloid precursor protein gene with familial Alzheimer's disease. Nature 349:704-706. https://doi.org/10.1038/349704a0

19. Gravina SA, Ho L, Eckman CB, Long KE, Otvos L, Younkin LH, Suzuki N, Younkin SG (1995) Amyloid $\beta$ protein (Aß) in Alzheimer's disease brain. Biochemical and immunocytochemical analysis with antibodies specific for forms ending at $A \beta 40$ or $A \beta 42(43)$. J Biol Chem 270:7013-7016

20. Haglund M, Kalaria R, Slade JY, Englund E (2006) Differential deposition of amyloid $\beta$ peptides in cerebral amyloid angiopathy associated with Alzheimer's disease and vascular dementia. Acta Neuropathol 111:430-435. https://doi.org/10.1007/s00401-006-0054-z

21. Hardy J, Mullan M, Chartier-Harlin MC, Brown J, Goate A, Rosso M, Collinge J, Roberts G, Luthert P, Lantos P, Naruse S, Kaneko K, Tsuji S, Miyatake T, Shimizu T, Kojima T, Nakano I, Yoshioka K, Sakaki Y, Miki T, Katsuya T, Ogihara T, Roses A, Pericak-Vance M, Haan J, Roos R, Lucotte G, David F (1991) Molecular classification of Alzheimer's disease. Lancet 337(8753):13421343. https://doi.org/10.1016/0140-6736(91)93011-W

22. Hardy J (2017) The discovery of Alzheimer-causing mutations in the APP gene and the formulation of the "amyloid cascade hypothesis". FEBS J 284: 1040-1044. https://doi.org/10.1111/febs.14004

23. Holtzman DM, Bales KR, Tenkova T, Fagan AM, Parsadanian M, Sartorius $L$, Mackey B, Olney J, McKeel D, Wozniak D, Paul SM (2000) Apolipoprotein E isoform-dependent amyloid deposition and neuritic degeneration in a mouse model of Alzheimer's disease. Proc Natl Acad Sci U S A 97:28922897. https://doi.org/10.1073/pnas.050004797

24. Hsiao K, Chapman P, Nilsen S, Eckman C, Harigaya Y, Younkin S, Yang F, Cole $G$ (1996) Correlative memory deficits, $A \beta$ elevation, and amyloid plaques in transgenic mice. Science (80- ) 274:99-102. https://doi.org/10. 1126/science.274.5284.99

25. Iwatsubo T, Mann DMA, Odaka A, Suzuki N, Ihara Y (1995) Amyloid $\beta$ protein $(A \beta)$ deposition: $A \beta 42(43)$ precedes $A \beta 40$ in down Syndrome. Ann Neurol 37:294-299. https://doi.org/10.1002/ana.410370305

26. Joachim CL, Duffy LK, Morris JH, Selkoe DJ (1988) Protein chemical and immunocytochemical studies of meningovascular $\beta$-amyloid protein in Alzheimer's disease and normal aging. Brain Res 474:100-111. https://doi. org/10.1016/0006-8993(88)90673-7

27. De Jonghe C, Esselens C, Kumar-Singh S, Craessaerts K, Serneels S, Checler F, Annaert W, Van Broeckhoven C, De Strooper B (2001) Pathogenic APP mutations near the gamma-secretase cleavage site differentially affect Abeta secretion and APP C-terminal fragment stability. Hum Mol Genet 10: 1665-1671. https://doi.org/10.1093/hmg/10.16.1665

28. Jonsson T, Atwal JK, Steinberg S, Snaedal J, Jonsson PV, Bjornsson S, Stefansson H, Sulem P, Gudbjartsson D, Maloney J, Hoyte K, Gustafson A, Liu Y, Lu Y, Bhangale T, Graham RR, Huttenlocher J, Bjornsdottir G, Andreassen OA, Jönsson EG, Palotie A, Behrens TW, Magnusson OT, Kong A, Thorsteinsdottir U, Watts RJ, Stefansson K (2012) A mutation in APP protects against Alzheimer's disease and age-related cognitive decline. Nature 488: 96-99. https://doi.org/10.1038/nature11283

29. Lantos PL, Luthert PJ, Hanger D, Anderton BH, Mullan M, Rossor M (1992) Familial Alzheimer's disease with the amyloid precursor protein position 717 mutation and sporadic Alzheimer's disease have the same cytoskeletal pathology. Neurosci Lett 137:221-224. https://doi.org/10.1016/0304-3940(92)90408-y

30. Levi O, Michaelson DM (2007) Environmental enrichment stimulates neurogenesis in apolipoprotein E3 and neuronal apoptosis in 
apolipoprotein E4 transgenic mice. J Neurochem 100:202-210. https://doi. org/10.1111/j.1471-4159.2006.04189.x

31. Levites $Y$, Das P, Price RW, Rochette MJ, Kostura LA, McGowan EM, Murphy MP, Golde TE (2006) Anti-Abeta42- and anti-Abeta40-specific mAbs attenuate amyloid deposition in an Alzheimer disease mouse model. J Clin Invest 116:193-201. https://doi.org/10.1172/JCI25410

32. Mann DMA, Davidson YS, Robinson AC, Allen N, Hashimoto T, Richardson A, Jones M, Snowden JS, Pendleton N, Potier MC, Laquerrière A, Prasher V, Iwatsubo T, Strydom A (2018) Patterns and severity of vascular amyloid in Alzheimer's disease associated with duplications and missense mutations in APP gene, Down syndrome and sporadic Alzheimer's disease. Acta Neuropathol 136:569-587. https://doi.org/10.1007/s00401-018-1866-3

33. McGowan E, Pickford F, Kim J, Onstead L, Eriksen J, Yu C, Skipper L, Murphy MP, Beard J, Das P, Jansen K, DeLucia M, Lin WL, Dolios G, Wang R, Eckman CB, Dickson DW, Hutton M, Hardy J, Golde T (2005) $A \beta 42$ is essential for parenchymal and vascular amyloid deposition in mice. Neuron 47:191-199. https://doi.org/10.1016/j.neuron.2005.06.030

34. Moechars D, Dewachter I, Lorent K, Reversé D, Baekelandt V, Naidu A, Tesseur I, Spittaels K, Haute CV, Checler F, Godaux E, Cordell B, Van Leuven $F(1999)$ Early phenotypic changes in transgenic mice that overexpress different mutants of amyloid precursor protein in brain. J Biol Chem 274 6483-6492. https://doi.org/10.1074/jbc.274.10.6483

35. Montine TJ, Phelps CH, Beach TG, Bigio EH, Cairns NJ, Dickson DW, Duyckaerts C, Frosch MP, Masliah E, Mirra SS, Nelson PT, Schneider JA, Thal DR, Trojanowski JQ, Vinters HV, Hyman BT, Aging NI on, Association A (2012) National Institute on Aging-Alzheimer's Association guidelines for the neuropathologic assessment of Alzheimer's disease: a practical approach. Acta Neuropathol 123:1-11. https://doi.org/10.1007/s00401-011-0910-3

36. Mullan MJ, Giuffra L, Hardy JA, Ovenstone I, Haynes AR, James LA, Williamson R, Newton PJ, Owen MJ, Roques P, Luthert P, Lantos P, Goate AM, Rossor MN (1991) Clinical and Pathologic Features of Chromosome 21Linked Familial Alzheimer's Disease. Ann NY Acad Sci 640(1):177-180. https://doi.org/10.1111/j.1749-6632.1991.tb00212.x

37. Murrell J, Farlow M, Ghetti B, Benson MD (1991) A mutation in the amyloid precursor protein associated with hereditary Alzheimer's disease. Science (80- ) 254:97-99. https://doi.org/10.1126/science.1925564

38. Murrell JR, Hake AM, Quaid KA, Farlow MR, Ghetti B (2000) Early-Onset Alzheimer Disease Caused by a New Mutation (V717L) in the Amyloid Precursor Protein Gene. Arch Neurol 57(6):885-887. https://doi.org/10.1001/ archneur.57.6.885

39. Nacmias B, Latorraca S, Piersanti P, Forleo P, Piacentini S, Bracco L, Amaducci L, Sorbi S (1995) ApoE genotype and familial Alzheimer's disease: a possible influence on age of onset in APP717 Val-->lle mutated families. Neurosci Lett 183:1-3. https://doi.org/10.1016/0304-3940(94)11100-w

40. Natté R, Yamaguchi H, Maat-Schieman MLC, Prins FA, Neeskens P, Roos RAC, Van Duinen SG (1999) Ultrastructural evidence of early non-fibrillar $A \beta 42$ in the capillary basement membrane of patients with hereditary cerebral hemorrhage with amyloidosis, Dutch type. Acta Neuropathol 98: 577-582. https://doi.org/10.1007/s004010051121

41. Nelson PT, Dickson DW, Trojanowski JQ, Jack CR, Boyle PA, Arfanakis K, Rademakers R, Alafuzoff I, Attems J, Brayne C, Coyle-Gilchrist ITS, Chui HC, Fardo DW, Flanagan ME, Halliday G, Hokkanen SRK, Hunter S, Jicha GA, Katsumata Y, Kawas CH, Keene CD, Kovacs GG, Kukull WA, Levey Al, Makkinejad N, Montine TJ, Murayama S, Murray ME, Nag S, Rissman RA, Seeley WW, Sperling RA, White lii CL, Yu L, Schneider JA (2019) Limbic-predominant agerelated TDP-43 encephalopathy (LATE): consensus working group report. Brain 142:1503-1527. https://doi.org/10.1093/brain/awz099

42. Nishitsuji K, Tomiyama T, Ishibashi K, Kametani F, Ozawa K, Okada R, Maat-Schieman ML, Roos RAC, Iwai K, Mori H (2007) Cerebral vascular accumulation of Dutch-type Abeta42, but not wild-type Abeta42, in hereditary cerebral hemorrhage with amyloidosis, Dutch type. J Neurosci Res 85:2917-2923. https://doi.org/10.1002/jnr.21413

43. Oakley H, Cole SL, Logan S, Maus E, Shao P, Craft J, Guillozet-Bongaarts A, Ohno M, Disterhoft J, Van Eldik L, Berry R, Vassar R (2006) Intraneuronal $\beta$ amyloid aggregates, neurodegeneration, and neuron loss in transgenic mice with five familial Alzheimer's disease mutations: potential factors in amyloid plaque formation. J Neurosci 26:10129-10140. https://doi.org/10. 1523/JNEUROSCI.1202-06.2006

44. Olichney JM, Hansen LA, Hofstetter CR, Grundman M, Katzman R, Thal $\sqcup$ (1995) Cerebral infarction in Alzheimer's disease is associated with severe amyloid Angiopathy and hypertension. Arch Neurol 52:702-708. https://doi.org/10.1001/archneur.1995.00540310076019

45. Prelli F, Castano E, Glenner GG, Frangione B (1988) Differences between vascular and plaque Core amyloid in Alzheimer's disease. J Neurochem 51:648-651. https://doi.org/10.1111/j.1471-4159.1988.tb01087.x

46. Quon D, Wang Y, Catalano R, Scardina JM, Murakami K, Cordell B (1991) Formation of $\beta$-amyloid protein deposits in brains of transgenic mice. Nature 352: 239-241. https://doi.org/10.1038/352239a0

47. Radde R, Bolmont T, Kaeser SA, Coomaraswamy J, Lindau D, Stoltze L, Calhoun ME, Jäggi F, Wolburg H, Gengler S, Haass C, Ghetti B, Czech C, Hölscher C, Mathews PM, Jucker M (2006) Aß42-driven cerebral amyloidosis in transgenic mice reveals early and robust pathology. EMBO Rep 7:940946. https://doi.org/10.1038/sj.embor.7400784

48. Ringman JM, Monsell S, Ng DW, Zhou Y, Nguyen A, Coppola G, Van Berlo V, Mendez MF, Tung S, Weintraub S, Mesulam MM, Bigio EH, Gitelman DR, Fisher-Hubbard AO, Albin RL, Vinters HV (2016) Neuropathology of autosomal dominant Alzheimer disease in the national Alzheimer coordinating center database. J Neuropathol Exp Neurol 75:284-290. https://doi.org/10.1093/jnen/nlv028

49. Rockenstein E, Mallory M, Mante M, Sisk A, Masliaha E (2001) Early formation of mature amyloid-beta protein deposits in a mutant APP transgenic model depends on levels of Abeta(1-42). J Neurosci Res 66:573-582. https://doi.org/10.1002/jnr.1247

50. Scahill RI, Ridgway GR, Bartlett JW, Barnes J, Ryan NS, Mead S, Beck J, Clarkson MJ, Crutch SJ, Schott JM, Ourselin S, Warren JD, Hardy J, Rossor MN, Fox NC (2013) Genetic influences on atrophy patterns in familial Alzheimer's disease: a comparison of APP and PSEN1 mutations. J Alzheimers Dis 35:199-212. https://doi.org/10.3233/JAD-121255

51. Shinkai $Y$, Yoshimura M, Ito $Y$, Odaka A, Suzuki N, Yanagisawa K, Ihara $Y$ (1995) Amyloid $\beta$-proteins $1-40$ and $1-42(43)$ in the soluble fraction of extra- and intracranial blood vessels. Ann Neurol 38:421428. https://doi.org/10.1002/ana.410380312

52. Sim RB, Dodds AW, Mitc DA, Reid KBM, Sc J (2014) Early-onset amyloid deposition and cognitive deficits in transgenic mice expressing a double mutant form of amyloid precursor protein $695^{*}$. J Biol Chem 281:1-11. https://doi.org/10.1074/jbc

53. Sorbi S, Nacmias B, Forleo P, Piacentini S, Latorraca S, Amaducci L (1995) Epistatic effect of APP717 mutation and apolipoprotein E genotype in familial Alzheimer's disease. Ann Neurol 38:124-127. https://doi.org/10.1002/ana.410380120

54. Sturchler-Pierrat C, Abramowski D, Duke M, Wiederhold KH, Mistl C, Rothacher S, Ledermann B, Bürki K, Frey P, Paganetti PA, Waridel C, Calhoun ME, Jucker M, Probst A, Staufenbiel M, Sommer B (1997) Two amyloid precursor protein transgenic mouse models with Alzheimer disease-like pathology. Proc Natl Acad Sci U S A 94:13287-13292. https://doi.org/10.1073/pnas.94.24.13287

55. Talarico G, Piscopo P, Gasparini M, Salati E, Pignatelli M, Pietracupa S, Malvezzi-Campeggi L, Crestini A, Boschi S, Lenzi GL, Confaloni A, Bruno G (2010) The London APP mutation (Val717lle) associated with early shifting abilities and behavioral changes in two Italian families with early-onset Alzheimer's disease. Dement Geriatr Cogn Disord 29:484490. https://doi.org/10.1159/000313541

56. Tang MX, Stern Y, Marder K, Bell K, Gurland B, Lantigua R, Andrews H, Feng L, Tycko B, Mayeux R (1998) The APOE-epsilon4 allele and the risk of Alzheimer disease among African Americans, whites, and Hispanics. JAMA 279:751-755. https://doi.org/10.1001/jama.279.10.751

57. Thal DR, Ghebremedhin E, Orantes M, Wiestler OD (2003) Vascular pathology in Alzheimer disease: correlation of cerebral amyloid Angiopathy and arteriosclerosis/Lipohyalinosis with cognitive decline. J Neuropathol Exp Neurol 62:1287-1301. https://doi.org/10.1093/jnen/62.12.1287

58. Thal DR, Ghebremedhin E, Rüb U, Yamaguchi H, Del Tredici K, Braak H (2002) Two types of sporadic cerebral amyloid angiopathy. J Neuropathol Exp Neurol 61:282-293. https://doi.org/10.1093/jnen/61.3.282

59. Thal DR, Papassotiropoulos A, Saido TC, Griffin WS, Mrak RE, Kölsch H, Del Tredici K, Attems J, Ghebremedhin E (2010) Capillary cerebral amyloid angiopathy identifies a distinct APOE epsilon4-associated subtype of sporadic Alzheimer's disease. Acta Neuropathol 120:169-183. https://doi.org/ 10.1007/s00401-010-0707-9

60. Thomas AJ, Morris CM, Ferrier IN, Kalaria RN (2000) Distribution of amyloid beta42 in relation to the cerebral microvasculature in an elderly cohort with Alzheimer's disease. Ann N Y Acad Sci 903:83-88. https://doi.org/10.1111/j. 1749-6632.2000.tb06353.x 
61. Vonsattel JPG, Myers RH, Tessa Hedley-Whyte E, Ropper AH, Bird ED, Richardson EP (1991) Cerebral amyloid angiopathy without and with cerebral hemorrhages: a comparative histological study. Ann Neurol 30:637649. https://doi.org/10.1002/ana.410300503

62. Waxman EA, Giasson BI (2008) Specificity and regulation of casein kinasemediated phosphorylation of alpha-synuclein. J Neuropathol Exp Neurol 67: 402-416. https://doi.org/10.1097/NEN.0b013e31816fc995

63. Zhang G, Xie Y, Wang W, Feng X, Jia J (2017) Clinical characterization of an APP mutation (V717l) in five Han Chinese families with early-onset

Alzheimer's disease. J Neurol Sci 372:379-386. https://doi.org/10.1016/j.jns. 2016.10.039

\section{Publisher's Note}

Springer Nature remains neutral with regard to jurisdictional claims in published maps and institutional affiliations.

Ready to submit your research? Choose BMC and benefit from:

- fast, convenient online submission

- thorough peer review by experienced researchers in your field

- rapid publication on acceptance

- support for research data, including large and complex data types

- gold Open Access which fosters wider collaboration and increased citations

- maximum visibility for your research: over $100 \mathrm{M}$ website views per year

At BMC, research is always in progress.

Learn more biomedcentral.com/submissions 